\title{
Elimination of Tool Failure in Edge Cutting Machine using Quality Tools and Techniques
}

\author{
D. Sakthimurugan, L. Antony Michael Raj, V. Antony Aroul Raj, K. Thavasilingam, N. Bharath
}

\begin{abstract}
Increasing cost of consumable materials has put an enormous pressure on the estimating as well as the costeffectiveness of an organization. Therefore, without any conciliation on quality, the unpredictable cost has to be reduced. This demands novel intellectual and creativity for constant improvement in manufacture, resulting in good earnings. Rim is an important component for any wheel and manufacturing of rim involves various stages with each stage involving different machines. The basic idea of the research is to identify the causes of tool failure in edge cutting machine and to find solution for the identified causes. Edge cutting machine is specially used in earthmovers unit for the production of rims for earthmover wheels. The existing tool was replaced with the new tool made of shearing resistant material. The new tool is designed and analysed for production purpose and cost variation are successfully compared.
\end{abstract}

Keywords-Quality Tools, PDCA, Activity Chart, Causes and Effect diagram.

\section{INTRODUCTION}

Maintain leadership in the national market and presence in export market. Ensure customer satisfaction through delivery of quality product and services, at viable prices. Continuously improve $\&$ innovative product design, process technology and working environment to offer enhanced products. Bring about participation of all employees in achieving the above objectives. "Totality of features and characteristics of a product or service that bears on its ability to meet stated or implied needs" -ISO. The tools are causeand-effect diagram, check sheet, histogram, pareto chart, scatter diagram and stratification. It is an iterative four-step management method used in business for the control and continuous improvement of processes and products. It is also known as the Deming cycle/ plan-do-check-act (PDCA).

\section{QUALITY TOOLS AND TECHNIQUES}

a. Seven Basic Quality tools

Revised Manuscript Received on 14 September, 2019.

D. Sakthimurugan, Department of Mechanical Engineering, Easwari Engineering College, Chennai, Tamil Nadu, India. (Email: skthids@gmail.com)

L. Antony Michael Raj, Department of Mechanical Engineering, Loyola-ICAM College of Engineering, City, Chennai, Tamil Nadu, India. (Email: antonymr@yahoo.com)

V. Antony Aroul Raj, Department of Mechanical Engineering, Easwari Engineering College, Chennai, Tamil Nadu, India. (Email: antonyaroulraj@gmail.com)

K. Thavasilingam, Department of Mechanical Engineering, Easwari Engineering College, Chennai, Tamil Nadu, India. (Email: thavasi.k89@gmail.com)

N. Bharath, Department of Mechanical Engineering, Easwari Engineering College, Chennai, Tamil Nadu, India.
It is a designation given to a fixed set of graphical techniques identified as being most helpful in troubleshooting issues related to quality. The tools are,

- Cause-and-Effect Diagram.

- Check sheet.

- Control charts.

- Histogram.

- Pareto chart.

- Scatter diagram.

- Stratification

The need for tools to promote innovation, communicate information and successfully plan major projects. A team researched and developed the seven new quality control tools, often called seven management tools.

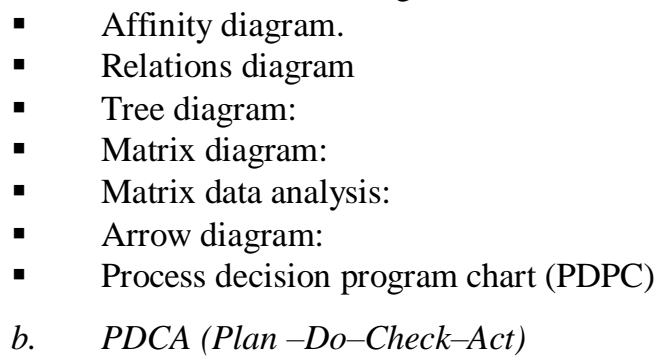

It is an iterative four-step management method used in business for the control and continuous improvement of processes and products. It is otherwise known as the Deming wheel, shewhart circle, control circle or plan-dostudy-act (PDCA).

\section{ACITIVITY CHART}

The sequence of process carried out throughout the project is depicted in the activity chart. It includes step by step process to analyze and eliminate the failure. 


\begin{tabular}{|c|c|c|c|c|c|c|c|c|}
\hline & & Jan & & & Feb & Iary & $\mathrm{Ma}$ & \\
\hline $\begin{array}{l}\text { S. } \\
\text { No }\end{array}$ & Activity & $\begin{array}{l}\text { W } \\
1\end{array}$ & $\begin{array}{l}\mathrm{W} \\
2\end{array}$ & $\begin{array}{l}\mathrm{W} \\
3\end{array}$ & $\begin{array}{l}\text { W } \\
4\end{array}$ & $\begin{array}{l}\mathrm{W} \\
5\end{array}$ & $\begin{array}{l}\text { W } \\
6\end{array}$ & $\begin{array}{l}\text { W } \\
7\end{array}$ \\
\hline 1 & $\begin{array}{l}\text { Define the } \\
\text { project }\end{array}$ & & & & & & & \\
\hline 2 & $\begin{array}{l}\text { Study the } \\
\text { current } \\
\text { situation }\end{array}$ & & & & & & & \\
\hline 3 & $\begin{array}{l}\text { Analyze the } \\
\text { potential } \\
\text { causes }\end{array}$ & & & & & & & \\
\hline 4 & $\begin{array}{l}\text { Develop the } \\
\text { solution }\end{array}$ & & & & & & & \\
\hline 5 & $\begin{array}{l}\text { Analyze the } \\
\text { results }\end{array}$ & & & & & & & \\
\hline 6 & $\begin{array}{l}\text { Standardize } \\
\text { the } \\
\text { improveme } \\
\text { nt }\end{array}$ & & & & & & & \\
\hline 7 & $\begin{array}{l}\text { Establish } \\
\text { future plans }\end{array}$ & & & & & & & \\
\hline
\end{tabular}

\section{LITERATURE SURVEY}

Before Narasimha et al., worked on the ways of improving the tool life by various coatings on tool steels. The coatings like TiN, Al2O3, TiN-Al2O3 are extends tools steels are investigated in dry condition. For comparison uncoated tool steels are tested under same condition. Surface roughness of the coated tool steel was greater than uncoated tool steel. Paliska et al., studied about the universality systematic in application of seven basic quality tools. The research was carried out in different areas of the manufacturing industry. The extend of selected tool in usage and the reasons for avoiding in broader application are studied. Also the core relation between the formal quality management system and seven basic quality tools is researched. Elmagrabi et al., studied many classification of tool materials. In most cases the tool manufacturers provide tools made of the proper material for each given application. In some particular application higher price material will be justified. The optimum tool is not necessarily the least expensive or the most expensive. The best tool is the one that has been carefully chosen to get the job done quickly, efficiently and economically. This paper shows that the response surface methodology can be used in design of experiment to develop tool life models for several materials and the same approach can be used for modeling other machineability performances such as surface roughness. Kumbhar et al., studied about tool failure and surface roughness prophecy. Taguchi approach is used to find the optimal process parameter for cutting semi hard steel. An orthogonal array, ANOVA and signal to noise ratio are used to study performance characteristics of machining parameters such as cutting speed with consideration of surface finish and tool life. The conclusions exposed that the feed rate is the most influential factor on the surface roughness and tool life.

\section{DEFINE THE PROBLEM}

\section{A. Edge cutting machine}

Generally a pair of tool is mounting on the either side of the tool holder. Tool used in edge cutting process is rectangular in shape with three counter bores provided for mounting the tool in the holder. The tool is mounted to the holder using allen bolt. The holder tightly holds the tool and it can move both horizontally and vertically. Only two counter bores are used to mount the tool and the other one remains free and is utilized in mounting other direction. The edge cutting tool has eight edges but only two edges are used for cutting process.

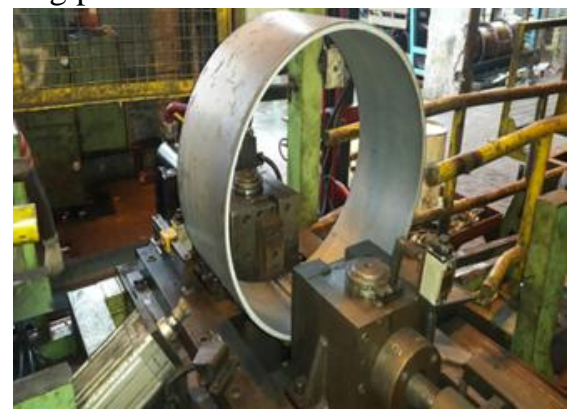

Fig 1: Edge cutting machine

\section{B. Edge cutting tool}

The The tool used in the Edge Cutting process is a 2 profile rectangular High Carbon High Chromium $(\mathrm{HcHcr})$ tool with 3 M12 Counter bore. The tool is attached to a tool holder. The issue is that it fails often with severe damages for every 1000 to 1200 rim productions

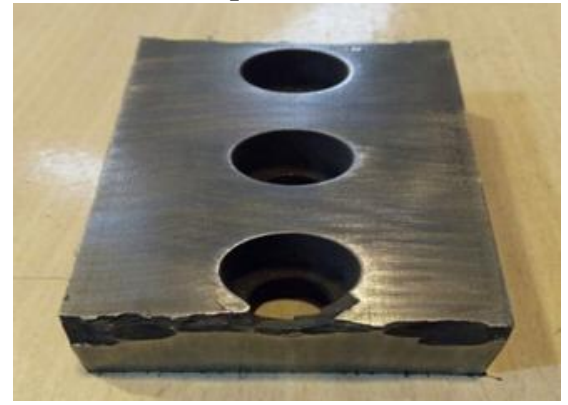

Fig 2 : Edge cutting machine

\section{Impact of the Problem}

Positioning Authors and Affiliations Tool change loss is the time lost while changing tools either due to breakage of tool or once the life of the tool is reached. Rim line is tool intensive lines in which around 200 types of tools are used. They are producing more than 1000 wheels per day. It means 1000 Edge cutting process is performed by the tool every day. Tool change loss due to edge cutting tool and holder breakage $\mathbf{= 5 5}$ minutes $/$ month

- Total tool change loss per month $=0.92$ hours

- Scheduled hours per day $=20.33$ hours

- Cost of rectangular type tool (one set) = Rs.4000

- Number of set used per month $=4$ set 
- Frequency of change due to failure per month = $4 * 4000 * 12=$ Rs. $1,92,000$

- So total cost of rectangular cutting tool per year for edge cutting operation is Rs. 1, 92,000.

\section{Edge cutting loss trend}

The time loss due to tool failure for a period of nine months is plotted using a run chart. And it is found that time loss varies between 40-65 minutes. So on an average the time loss is 55 minutes per month.

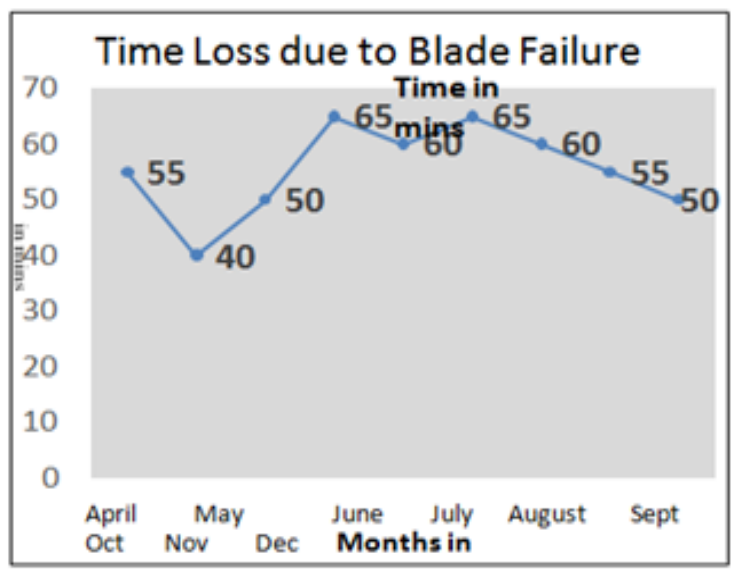

Fig 3: Edge cutting time loss trend

\section{IDENTIFING THE CAUSES}

The causes for the problems can be identified by brainstorming techniques

\section{A. Brainstorming}

It is a group or individual person, creativity technique by which efforts are made to find a conclusion for a specific problem by gathering a list of ideas impulsively contributed by its members. The following are the possible causes find by brainstorming techniques for edge cutting tool failure,
- Excess stress at cutting edge

- Weak design for blade

- Improper material for blade

- Improper fixing of blade holder

- Hardness in tool is insufficient

- Mill scales get trapped inside the tool

- Insufficient cutting pressure

- Excess stress concentration in tool

\section{B. Fishbone diagram}

It used to determine major causes for an effect and sorts ideas into useful meaningful categories namely - man machine, material, method. The possible causes of tool failure identified by brainstorming is sorted into four categories using the cause and effect diagram.

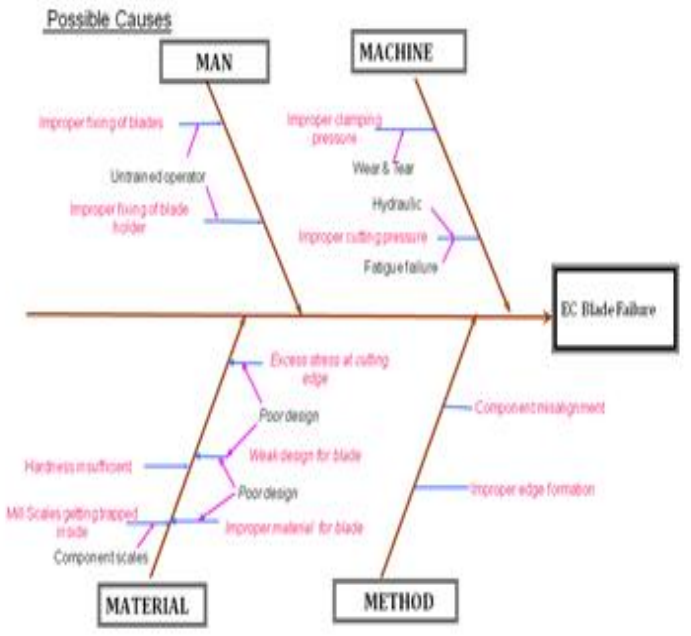

Fig 4 : Edge cutting time loss trend

C. Validating the possible causes

Table- II: Validation of causes of tool failure

\begin{tabular}{|c|c|c|}
\hline Causes & $\begin{array}{l}\text { Considered/ } \\
\text { Considered }\end{array}$ & Reasons for Eliminating the Causes \\
\hline 1. Excess stress at cutting edge & Considered & NA \\
\hline 2. Weak design for blade & Considered & NA \\
\hline 3. Improper material for blade & Considered & NA \\
\hline 4. Improper fixing of blade holder & Not considered & $\begin{array}{l}\text { Only Skilled technicians are involved in } \\
\text { tool change over in Edge cutting machines }\end{array}$ \\
\hline 5. Hardness in tool is insufficient & Not considered & $\begin{array}{l}\text { The blade hardness is observed to be } 52-54 \\
\text { HRC which is sufficient for the operation }\end{array}$ \\
\hline 6. Mill Scales get trapped inside the tool & Not considered & $\begin{array}{l}\text { Blade is bolted with blade holder. Space is } \\
\text { minimal for scales to enter }\end{array}$ \\
\hline 7. Insufficient cutting pressure & Not considered & $\begin{array}{l}\text { The cutting pressure was observed to be } 60 \\
\text { bar which is sufficient for the cutting off } \\
\text { the edges }\end{array}$ \\
\hline
\end{tabular}


Elimination Of Tool Failure In Edge Cutting Machine Using Quality Tools And Techniques

\begin{tabular}{|l|l|l|}
\hline 8. Existing blade width is high & Not considered & $\begin{array}{l}\text { Blade failure at the vertical section not } \\
\text { observed after analysis of tool }\end{array}$ \\
\hline 9.Insufficient clamping pressure & Not considered & Clamping pressure is 50 bar \\
\hline 10.Component misalignment & Not considered & $\begin{array}{l}\text { Component fed through automation and } \\
\text { width is sufficient for component alone }\end{array}$ \\
\hline 11. Improper edge formation & Not considered & $\begin{array}{l}\text { The size of edge variation was observed } \\
\text { between } 0.5 \text { to } 2 \text { mm only }\end{array}$ \\
\hline 12. Improper fixing of blade & Not considered & $\begin{array}{l}\text { Only Skilled technicians are involved in } \\
\text { tool change over in Edge cutting machines }\end{array}$ \\
\hline
\end{tabular}

\section{ANALYSIS THE ROOT CAUSES OF TOOL FAILURE}

The root causes are analyzed individually with the help of ANSYS work bench software.

\section{A. $\quad$ Calculation of stress}

Cutting force, $\mathrm{F}=\mathrm{A} \times \mathrm{T} \beta$

$$
\begin{aligned}
A & =\text { Shear area } \\
A & =\mathrm{L} \times \mathrm{S} \\
\mathrm{L} & =\text { Total cutting length } \\
\mathrm{S} & =\text { Material thickness } \\
\mathrm{T} \beta & =\text { shear strength }
\end{aligned}
$$

Note: Shear strength $\quad=80 \%$ of tensile strength So,

Tensile strength $\sigma \quad=258 \mathrm{Mpa}$

Shear strength $\mathrm{T} \beta \quad=0.80 \times 258$

Shear strength, $\mathrm{T} \beta \quad=207 \mathrm{Mpa}=207 \mathrm{~N} / \mathrm{mm} 2$

Material thickness, $\mathrm{S} \quad=3.5 \mathrm{~mm}$

Total cutting length, $\mathrm{L}=$

$10 \mathrm{~mm}$

Shear area, A

$=\mathrm{L} \times \mathrm{S}$

Shear area, A

$=10 \times 3.5$

Cutting force, $\mathrm{F}$

$$
=35 \mathrm{~mm} 2
$$$$
=\mathrm{A} \times \mathrm{T} \beta
$$$$
=35 \times 207
$$

Cutting force
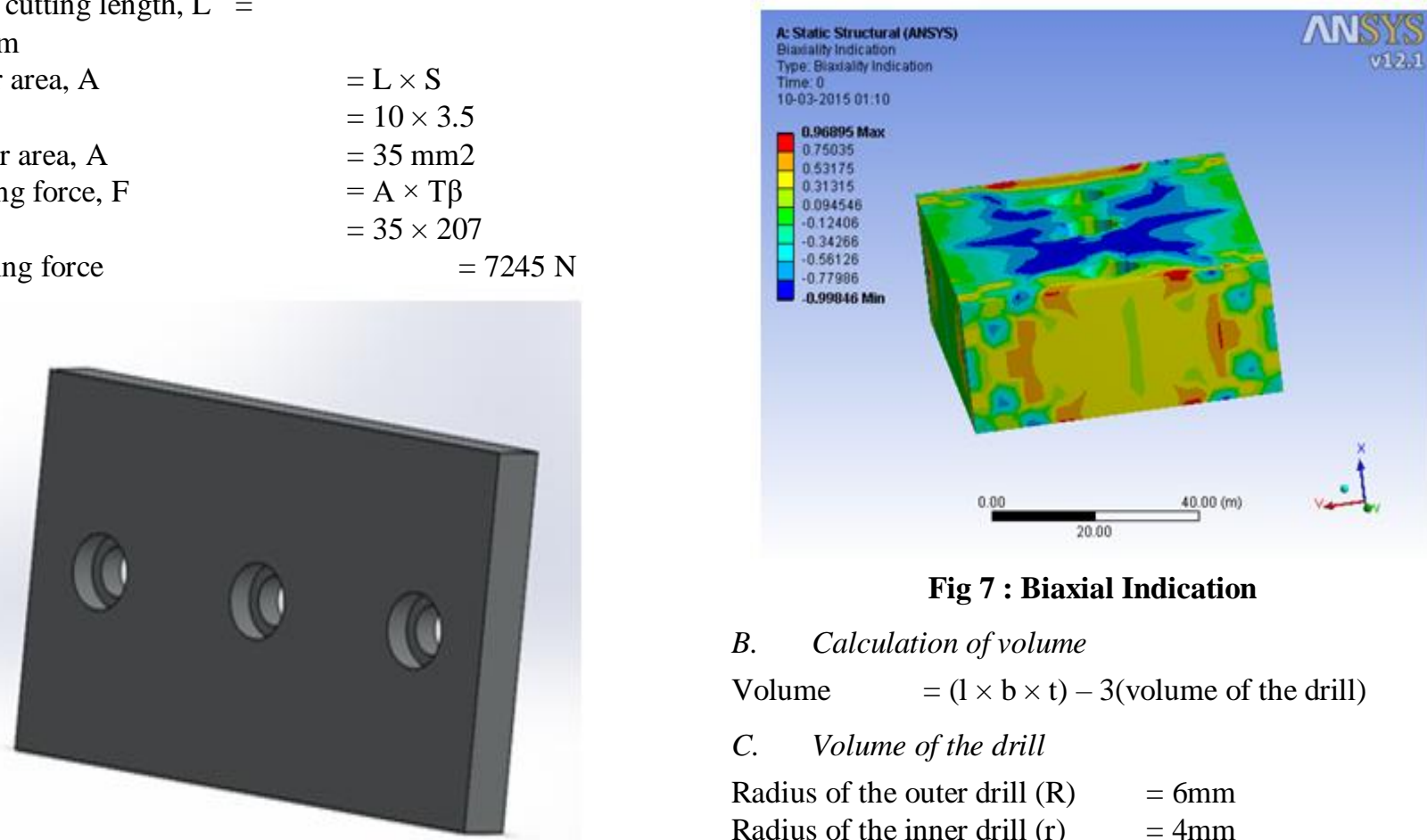

Fig 7 : Biaxial Indication

B. Calculation of volume

Volume $\quad=(1 \times b \times t)-3($ volume of the drill $)$

C. Volume of the drill

Radius of the outer drill (R) $\quad=6 \mathrm{~mm}$

Radius of the inner drill $(\mathrm{r}) \quad=4 \mathrm{~mm}$

Fig 5: 3D view of old tool 
Height of the drill (h)

Volume of the drill

$=12.5 \mathrm{~mm}$
$=(\pi \times \mathrm{R} 2 \times \mathrm{h})+(\pi \times \mathrm{r} 2 \times \mathrm{h})$

Volume of the drill $=(\pi \times 62 \times 12.5)+(\pi \times 42 \times 12.5)$

$$
\begin{aligned}
=(\pi & \times 36 \times 12.5)+(\pi \times 16 \times 12.5) \\
& =(\pi \times 450)+(\pi \times 200) \\
& =\pi(450+200) \\
& =\pi \times 520
\end{aligned}
$$

Volume of the drill $=204 \mathrm{~mm}^{3}$

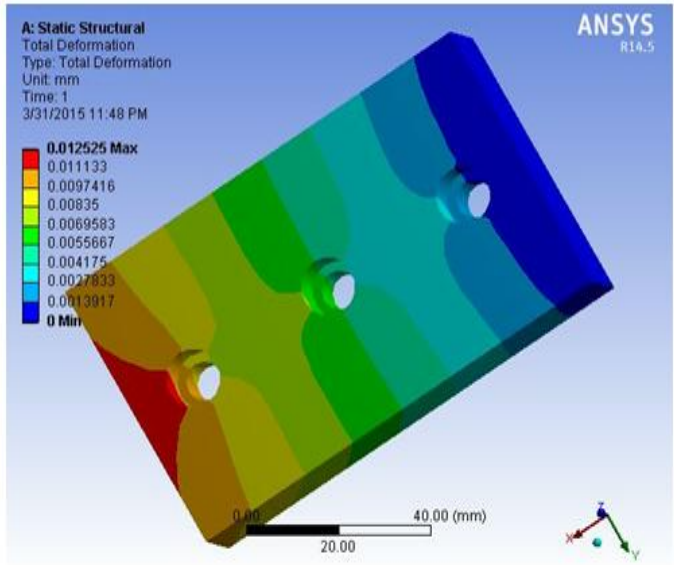

Fig 8: Total deformations due to stress

\section{Volume of the Old Tool}

Length of the old tool (1)

Breadth of the old tool (b)

Thickness of the old tool (t)

Volume of the drill

Volume of the old tool $=(1 \times b \times t)-3$ (volume of the drill)

$$
\begin{aligned}
& =(100 \times 70 \times 25)-3(2041) \\
& =175000-6123
\end{aligned}
$$

Volume of the old tool $=168877 \mathrm{~mm} 3$

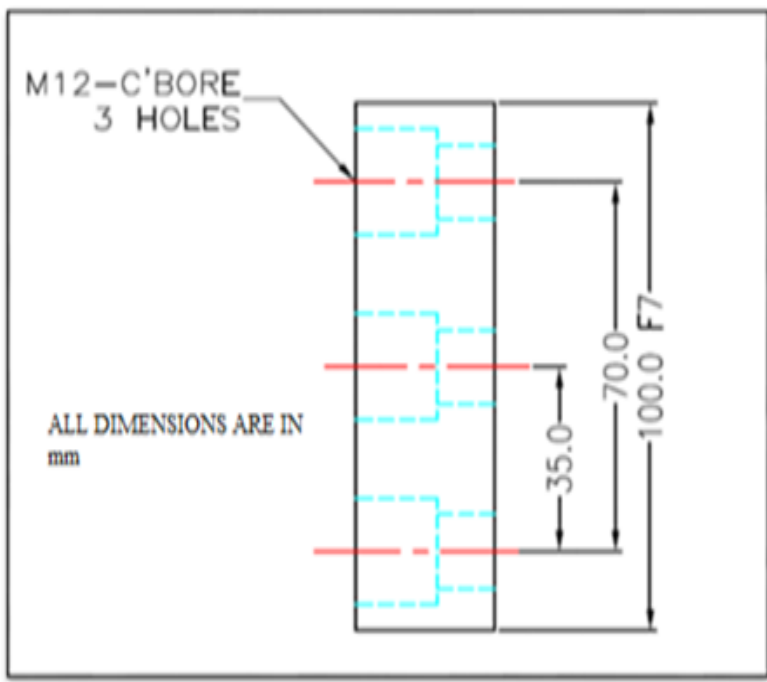

Fig 9: Side view of old tool

The 3 Counter bores covers a significant volume in the tool, which reduces the strength of the tool.

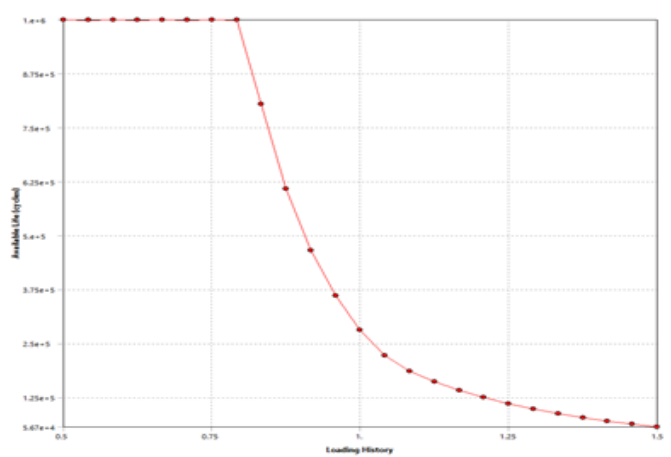

Fig 10: Fatigue sensitivity curve

E. Improper material for Tool

Existing tool is made up of high carbon high chromium D2 steel.

Table- II: Chemical composition of HCHCR

\begin{tabular}{|l|l|l|}
\hline S. No & Element & Content \% \\
\hline 1 & Carbon $(\mathrm{C})$ & $1.4-1.60$ \\
\hline 2 & Manganese (Mn) & 0.60 \\
\hline 3 & Silicon (Si) & 0.60 \\
\hline 4 & Cobalt (Co) & 1.00 \\
\hline 5 & Chromium (Cr) & $11-13$ \\
\hline 6 & Molybdenum (Mo) & $0.70-1.20$ \\
\hline 7 & Vanadium (V) & 1.10 \\
\hline 8 & Phosphorous (P) & 0.03 \\
\hline 9 & Nickel (Ni) & 0.30 \\
\hline 10 & Copper $(\mathrm{Cu})$ & 0.25 \\
\hline 11 & Sulphur $(\mathrm{S})$ & 0.03 \\
\hline
\end{tabular}

High carbon high chromium steels usually contain high carbon content (1.4 to $1.60 \%)$. Hence they are not suitable for shearing operations well. So we have planned to find another material that suits for shearing operation.

\section{Load calculation for the existing Tool}
Factor of Safety
$=3$
Ultimate Tensile Strength $\quad=258 \mathrm{MPa}$

$\mathrm{P}$ tool $\quad=\sigma$ ultimate $\times$ Area of tool $(\mathrm{A})$

$\mathrm{P}$ tool $\quad=\sigma$ ultimate $\times 7000$

$\mathrm{P}$ tool $\quad=258 \times 7000$

$$
=1806000 \mathrm{~N}
$$

P tool $=1806.000 \mathrm{KN}$

Safety load that can be applied on the old tool is $1806 \mathrm{KN}$

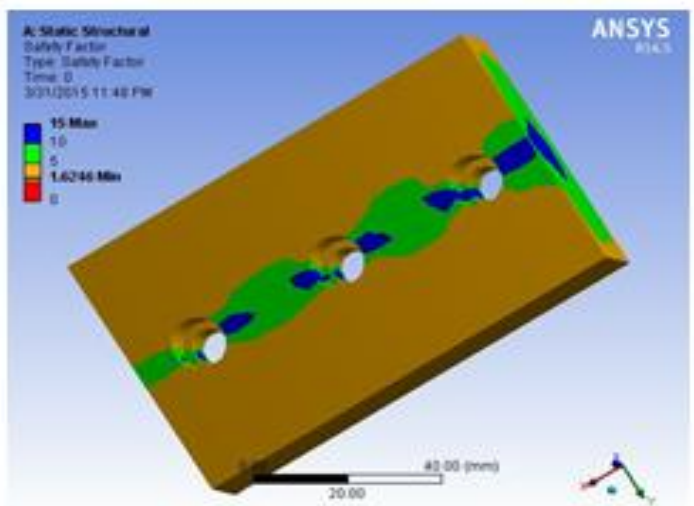

Fig 11: Safety factor 


\section{F. $\quad$ Existing Tool holder}

The existing old tool is mounted on a holder, which holds the tool during the cutting operation.

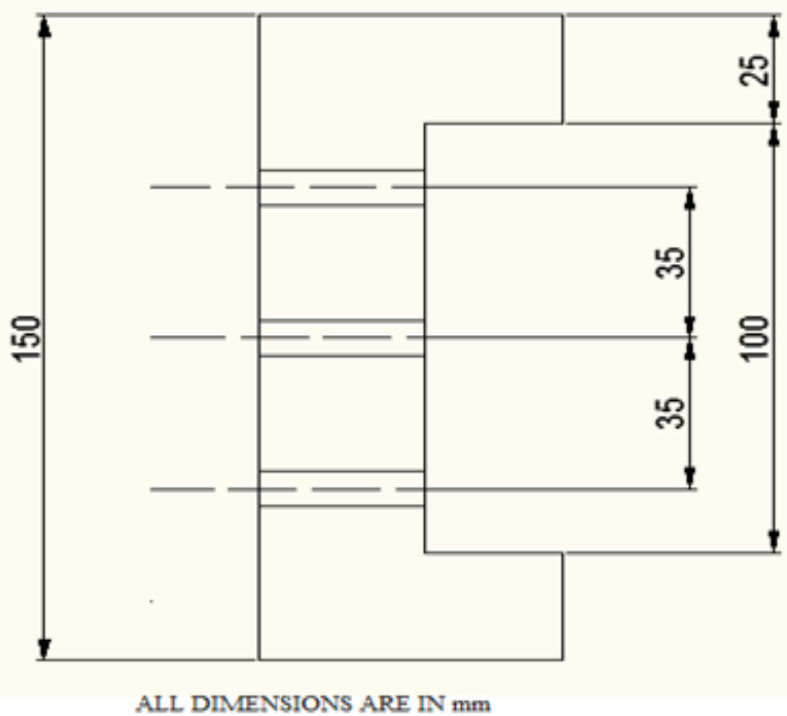

Fig 12: Existing Tool holder

Volume of the existing holder in $\mathrm{mm} 3=$ Area $\times$ Height Area of the holder (A1) $=1 \times \mathrm{b}=150 \times 25$

Area of the holder (A1) $=3750 \mathrm{~mm} 2$

Area2 (A2)

$$
=15 \times 15
$$

Area2 in $\mathrm{mm} 2$

$$
=225 \mathrm{~mm} 2
$$

(A3)

Area3 in $\mathrm{mm} 2$

$$
=225 \mathrm{~mm} 2
$$

Total Area (A)

$+\mathrm{A} 2+\mathrm{A} 3$

$$
=3750+225+225
$$

Total area in $\mathrm{mm} 2$ $\mathrm{mm} 2$

Volume of the holder Height

Height of the holder

$$
=15^{*} 15
$$

Volume of the holder

\section{DEVELOPING THE SOLUTION}

\section{A. Increasing work Area}

There is insufficient area for load at cutting edge, so we suggested changing the front fixing to rear fixing so that sufficient area for load at the cutting edge is achieved. Since the old tool is rectangular in shape, it can be used only on two cutting edges, but if the tool is in square shape it can be used on four sides, which will eventually decrease the tool change loss.

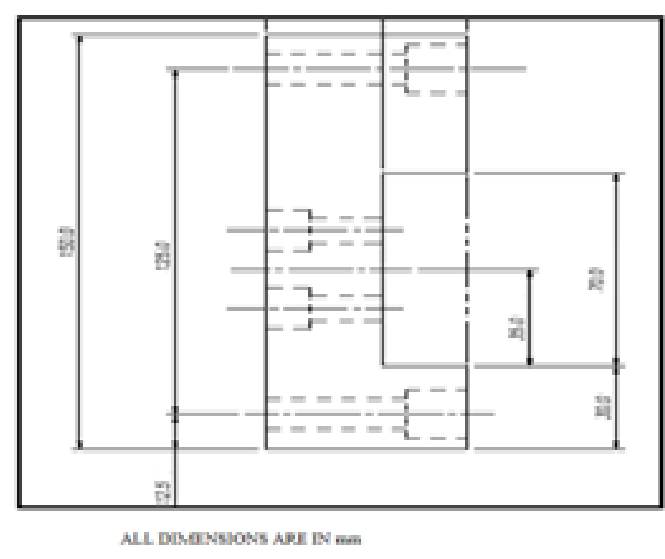

Fig 13: Rear Fixing

B. Alternate Design

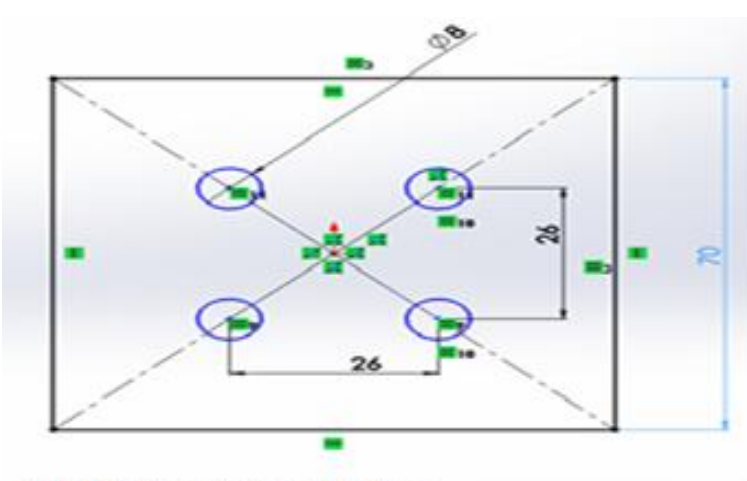

ALL DIMENSIONS ARE IN mm

Fig 14: 2D sketch of modified tool

Since the old tool has 3 M12 counter bores which occupies a significant area in the tool, it was decided to change the counter bores into 4 M8 tap holes. Now the counter bore is shifted to the holder. The advantage is that now the tool can be used on 8 edges compared to 2 edges in old rectangular tool.

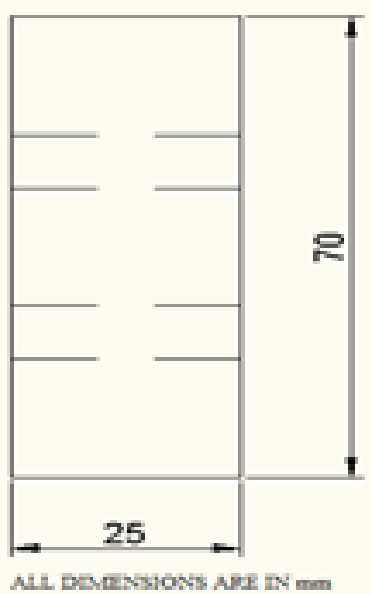

Fig 15 Side view of modified tool 


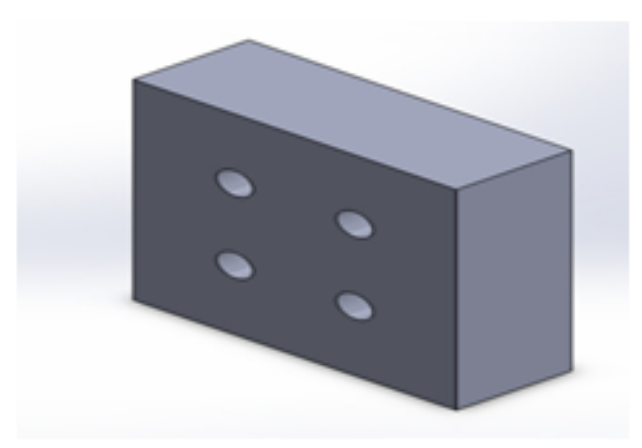

Fig 16 3D model of new tool

\section{Alternate Material}

With reference to ASM specialty handbook: Tool Materials we decided to choose S-7 tool material. As compared to HcHcr D2, S7 material has low carbon content. It contains only $0.55 \%$ of carbon. So it offers high roughness to endure chipping and breaking combined with high possible hardness (58 HRC) and fine wear resistance. Hence S7 material was chosen and the tool is designed and analysed.

Table- II: Chemical composition of S7 material

\begin{tabular}{|c|l|c|}
\hline S. No & \multicolumn{1}{|c|}{ Element } & Content \% \\
\hline 1 & Carbon (C) & 0.55 \\
\hline 2 & Manganese (Mn) & 0.70 \\
\hline 3 & Chromium (Cr) & 3.25 \\
\hline 4 & Molydodenum (Mo) & 1.40 \\
\hline 5 & Vanadium (V) & 0.25 \\
\hline 6 & Silicon (Si) & 0.35 \\
\hline
\end{tabular}

As per new design and dimension, the new edge cutting tool was developed. This new tool was made of S7 material. When compared to old tool material, S7 material tool is smaller in size and the three tap holes occupies only little area. So the working area is larger when compared to old tool. Since it is square shaped all the eight edges can be mounted as working edge one after another.

S7 material has incomparable collision properties in addition with highest hardenability of shock resisting grades of tool steel. It also possesses fine softening resistance at high temperatures which gives it hot work capabilities. Because of its unusual combination of properties, S7 is suitable for a wide range of tool applications. S7 has good polish ability in the hardened and tempered condition. S7 offers roughness to endure chipping and breaking, combined with high achievable hardness and good wear resistance.

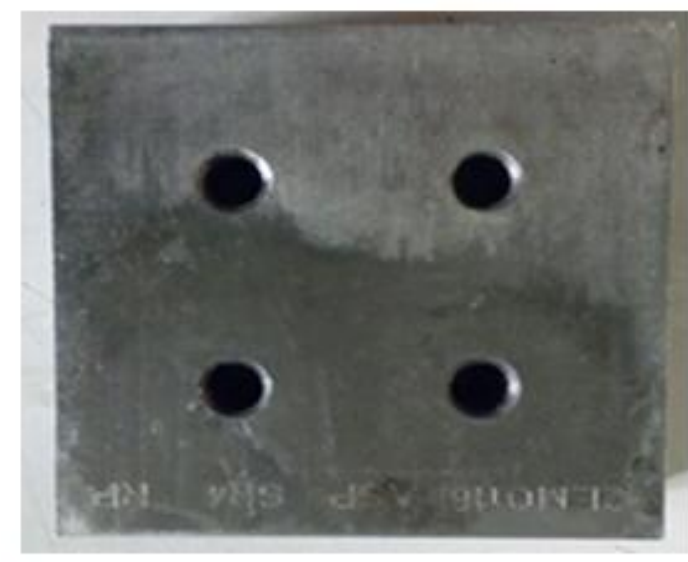

Fig 17 New tool developed using S7 material

\section{CALCULATION AND ANALYSIS FOR NEW TOOL}

\section{A. Volume of new tool}

Volume of the new tool in $\mathrm{mm}^{3}=$ Casting volume of the tool-Volume of tap holes.

Casting volume of the tool

Length of the side of the tool

$$
=70 \mathrm{~mm}
$$

Casting Volume of the new tool in $\mathrm{mm}^{3}=\mathrm{a}^{3}$

$$
=70 \times 70 \times 70
$$

Casting volume of the new tool in $\mathrm{mm}^{3}=343000 \mathrm{~mm}^{3}$

\section{Volume of the hole}

Diameter of the hole

Radius of the hole

Height of the hole

Volume of the single hole

Volume of the single hole

$$
\begin{aligned}
=8 \mathrm{~mm} & \\
& =4 \mathrm{~mm} \\
& =25 \mathrm{~mm} \\
& =\pi r^{2} \mathrm{~h} \\
& =\pi \times 4^{2} \times \mathrm{h} \\
& =\pi \times 16 \times 25 \\
& =\pi \times
\end{aligned}
$$

320

Volume of the single hole

Volume of four holes

$=1005.30 \mathrm{~mm} 2$

$$
=4 \times
$$

1005.30

Volume of four holes $4021.2 \mathrm{~mm} 3$

Volume of the new tool

Casting volume of the tool - Volume of the tap holes

$$
=343000-
$$

\section{2}

Volume of the new tool $\quad=338978.8 \mathrm{~mm}^{3}$

B. Load that tool can be with stand and by the tool

Load applied on the new tool

Factor of Safety $=3$

Ultimate Tensile strength of the tool material (UTS) $=$ $780 \mathrm{MPa}$

$\mathrm{P}$ tool $\quad=\sigma$ ultimate $\times$ Area of tool $(\mathrm{A})$ 


\section{Elimination Of Tool Failure In Edge Cutting Machine Using Quality Tools And Techniques}

\begin{tabular}{|c|c|}
\hline P tool & $=\sigma$ ultimate $\times 4900$ \\
\hline P tool & $\begin{aligned}=365 \times & 4900 \\
= & 1788500 \mathrm{~N}\end{aligned}$ \\
\hline Ptool & $=1788.5 \mathrm{KN}$ \\
\hline
\end{tabular}

Safety load that can be with stand by the new tool is $1788.5 \mathrm{KN}$

\section{Volume of new tool holder}

Since the tool is changed, we have to change the dimensions of the holder so that the new tool can be fixed.

Area of the holder (A1)

Area of the holder (A1) $3750 \mathrm{~mm} 2$

Area of the holder (A2)

Area of the holder (A3)

Area of the holder (A3)

Total area of the holder $(\mathrm{A})$

Total area of the holder (A)

Volume of the new holder

Volume of the new holder
Area of the holder (A2)

$$
\begin{aligned}
& =1 \times b \\
& =150 \times 25
\end{aligned}
$$$$
=45 \times 15
$$$$
=675 \mathrm{~mm} 2
$$$$
=15 \times 15
$$$$
=225 \mathrm{~mm} 2
$$$$
=\mathrm{A} 1+\mathrm{A} 2+\mathrm{A} 3
$$$$
=3750+675+225
$$$$
=4650 \mathrm{~mm} 3
$$$$
=\text { Area } \times \text { height }
$$$$
=4650 \times 70
$$$$
=325500 \mathrm{~mm} 3
$$

\section{Load that tool can be with stand and by the tool}

The new tool is analyses after the design is changed using ANSYS work bench software.

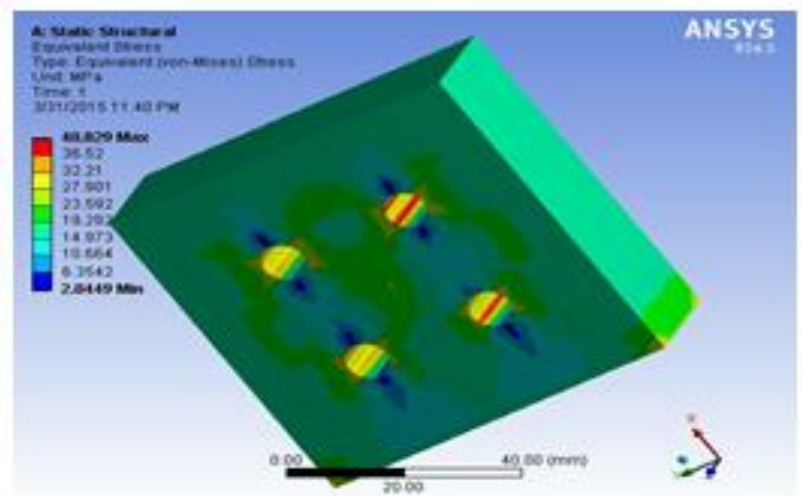

Fig 18 Von-mises analysis of new tool

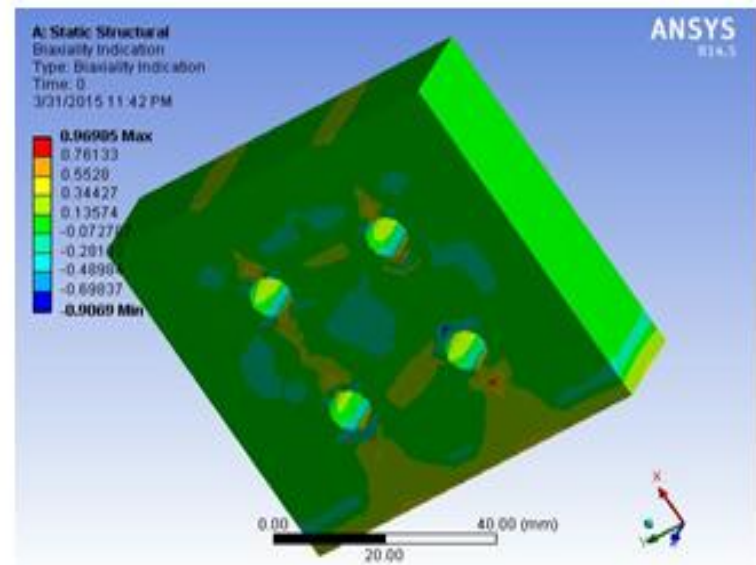

Fig 19 Biaxiality indication

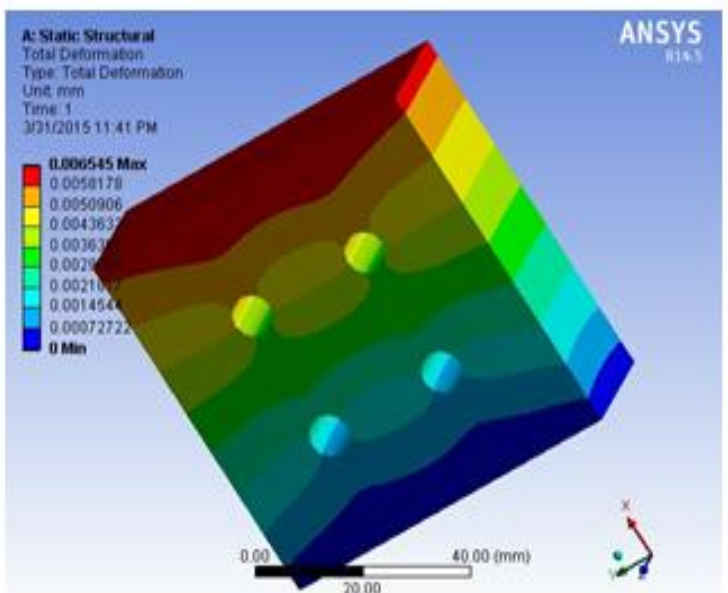

Fig 20 Deformation of new tool

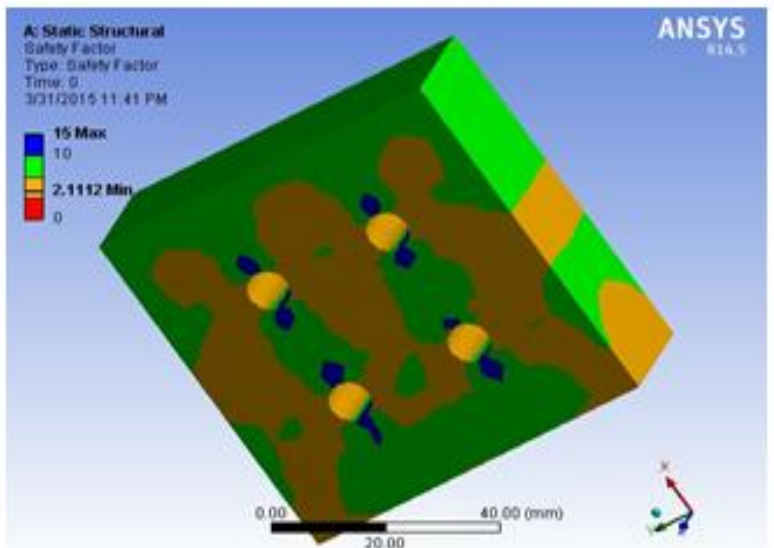

Fig 21 Safety factor of new tool

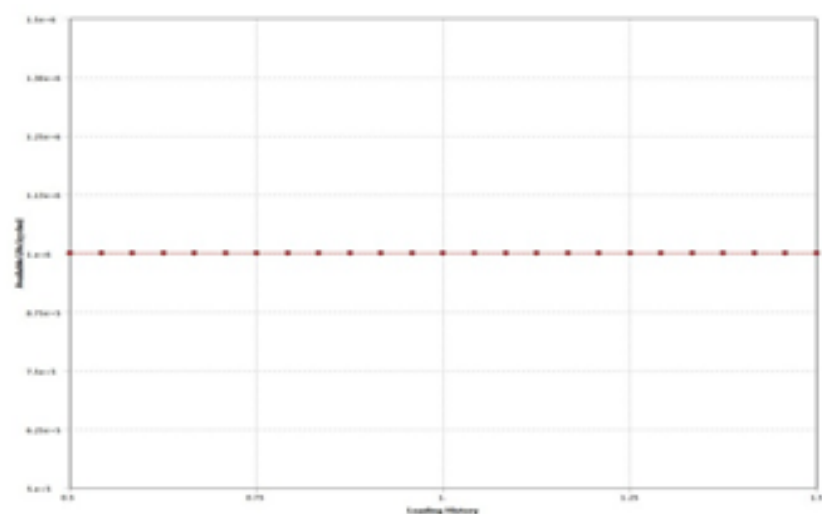

Fig 22 Fatigue sensitivity curve for new tool

\section{FORESEEING BENEFITS \& RESULTS}

\section{A. Tangible Benefits}

The productivity improvement after eliminating the tool failure is shown in the table. It is observed that the productivity is increased to 8 to 10 wheels per month.

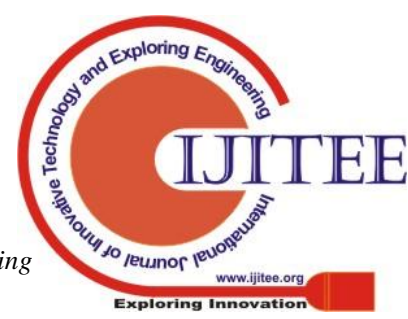


Table- II: Productivity improvement due to new tool

\begin{tabular}{|l|l|l|}
\hline $\begin{array}{l}\text { Tool change loss due to } \\
\text { EC blade and holder } \\
\text { breakage }\end{array}$ & 55 & Min/Month \\
\hline $\begin{array}{l}\text { Total Tool change loss } \\
\text { per month }\end{array}$ & 0.92 & Hours \\
\hline Scheduled hours per day & 20.33 & Hours \\
\hline $\begin{array}{l}\text { Current wheel } \\
\text { productivity achieved } \\
\text { per month }\end{array}$ & 3462 & Wheels \\
\hline $\begin{array}{l}\text { Extra wheels produced } \\
\text { due to elimination of } \\
\text { TC loss }\end{array}$ & $8-10$ & Wheels(appx) \\
\hline
\end{tabular}

\section{Cost savings} loss

Extra wheels produced due to elimination of tool change

$=8$ wheels

Opportunity cost of the wheel

$=2600 /$ wheel

Per day opportunity cost

$$
=792 \text { Rs/day }
$$

Cost benefits per annum $=$

2.5lakhs

\section{B. Intangible Benefits}

\section{Safety}

- $\quad$ Handling reduced which improves safety.

- $\quad$ Frequent adjustments eliminated.

\section{Morale}

- $\quad$ Fatigue reduced

- $\quad$ Operator morale improved.

Comparison of productivity between old tool and new tool

\section{Tool modification cost}

- Cost of old rectangular tool (two sides) per set $=$ 0.04 lakhs

- $\quad$ Frequency of change due to failure per month $=4$ set

- Total cost per annum $=4 \times 0.04 \times 12$

- Total cost per annum $=1.92$ lakhs

- $\quad$ Approximate cost of new square tool per set $=0.03$ lakhs

- $\quad$ Frequency of change for new tool (approximate) $=$ 1 set $/ 4$ months

- Total cost of new square type tool for one year = $0.03 \times 0.25 \times 12$

- Total cost of new square type tool for one year = 0.09 lakhs

- $\quad$ Saving in tool cost due to tool modification $=1.92$ 0.09

- $\quad$ Estimated tool cost that can be saved $=1.83$ lakhs

Thus the tool modification cost is reduced from 1.92 lakhs to 0.09 lakhs per annum.

\section{CONCLUSION}

Thus the project on "Elimination of tool failure in edge cutting machine using quality tools and techniques" is successfully carried out in the earthmovers rim unit of Wheels India, Padi .Without compromising on quality a new tool has been designed with alternate material which is both cost efficient and productive than the old tool. The new tool can be implemented in other rim lines with necessary analysis in similar edge cutting machines. The project has been done with sufficient quality tools and problem solving techniques used commonly in industries. By eliminating the tool change loss for a particular month, the productivity is improved upto 8-10 wheels a month. Apart from tangible benefits, it helps to achieve many intangible benefits. On completion of this project, it helped us to gain industrial knowledge on manufacturing process, quality assurance, tool design, engineering materials.

\section{REFERENCES}

1. W.Y.H.Liew, "Low speed milling of stainless steel with single layer and nano multilayer coated carbide tools under different lubrication circumstances," in Elsevier,Vol. 269, pp. 617-631.

2. J. Paulo Davim, Luís Figueira, "Machinability assessment in hard turning of cold work tool steel with ceramic tools using statistical tools and techniques," in materials and design, Vol. 28(4), 2007, pp. 1186-1191.

3. V.N.Gaitondea, S.R.Karnik, Luis Figueira and J.Paulo Davimc, "Machinability investigate in hard turning of cold work tool steel with predictable and wiper ceramic inserts," Vol. 27(4), July 2009, pp. 754-763.

4. M. Sokovića,.Barišić and S.Sladić, "Develop the framework of quality management of hard coatings on ceramic cutting tools," in Journal of materials processing technology, Vol 209(8), 21st April 2009, pp. 4207-4216.

5. E.Aslan, "Experimental investigation of cutting tool performance in high speed cutting of hardened cold-work tool steel" in materials and design Vol. 26(1) February 2005, pp. 21-27.

6. P.Bhattacharyyaa, D.Senguptaa and.Mukhopadhyay, "Cutting force-based real-time inference of tool wear in face milling using a combination of signal processing techniques," in Mechanical systems and signal processing, Vol. 21(6), August 2007, pp. 2665-2683.

7. Xiaona Luan, Song Zhang, and Jianfeng Li, "Trade-off examination of tool wear, quality of machining and energy efficiency of alloy cast iron milling process," Volume 26, 2018, pp. 383-393.

8. J.Fernández-Pérez, J.L.Cantero, J. Díaz Álvarez and M. H.Miguélez, "Composite fiber reinforced plastic oneshoot drilling, evaluation of quality inspection and tool wear," Vol. 13, 2017, pp. 139-145.

9. M.Rizala, J.A.Ghani, M.Z.Nuawi, and C.H.C.Haron, "Cutting tool wear classification and finding using multisensor signals and Mahalanobis Taguchi methods in wear", Vol. 376-377, April 2017, pp. 1759-1765.

10. Rodolfo E,.Haber, Jose E,Jiménez C..Ronei Peres, José R and Alique, "An investigation of tool-wear monitoring in a high-speed machining process," in actuators and sensors, Physical, Vol. 116(3), October 2004, pp 539-545

11. S.S.Bosheh, P.T.Mativenga, "White layer development in hard turning of H13 tool steel at high cutting speeds using CBN tooling," in International journal of machine tools and manufacture Vol 46(2), february 2006, pp. 225 233.

12. Anil Mital, Anoop Desai, Anand Subramanian and Aashi Mital, "Design review: Designing to ensure quality," in

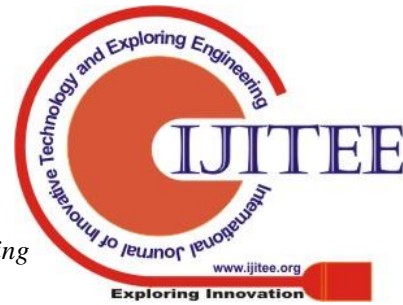


Product development, 2008, pp 71-91.

13. M.J.Bermingham, S.Palanisamy, M.S.Dargusch, "Considerate the tool wear mechanism during thermally assisted machining Ti-6Al-4V," in International journal of machine tools and manufacture, Vol. 62, November 2012, Pages 76-87.

14. C.Y.Wang, Y. X. Xie. Z. Qin H. S. Lin. Y. H. Yuan Q. M. Wang, "Wear and breakage of TiAlN- and TiSiNcoated carbide tools during high-speed milling of hardened steel," in Elsevier,Vol. 336-337, pp. 29-42.

15. N.Fang, Q.Wu, "A Comparative study of the cutting forces in high speed machining of Ti-6Al-4V and Inconel 718 with a round cutting edge tool," in Journal of materials processing technology, Vol. 209, (9), may 2009, pp. 4385-4389.

16. T.Özel, M.Sima, A.K.Srivastava and B.Kaftanoglu, "Studies on the effects of multi-layered coated inserts in machining Ti-6Al-4V alloy with trials and finite element models," in CIRP Annals, Vol 59(1), 2010, pp. 77-82.

17. Chung-Shin Chang, "Prediction of cutting forces for the milling of plain carbon steel using chamfered main cutting edge tools," in Journal of materials processing technology, Vol. 105(3), september 2000, pp. 302-326.

18. Joseph Berk, Susan Berk, "Managing for quality in the advanced environment: what American industry," in Quality management for the technology sector, 2000, pp. $1-5$.

19. Anne Thobor, Christophe Rousselot, Christine Clement and Jamal Takadoum, "Enhancement of mechanical properties of TiN/AIN multilayers by modify the number and the quality of interfaces," in Elsevier, Vol. 124(2-3), February 2000, pp. 210-221.

20. F.Klocke, H.Kratz, "Advanced tool edge geometry for high precision hard Turning," in CIRP Annals, Vol. 54(1), 2005, pp. 47-50.

21. G.List, M.Nouari, D.Géhina, S.Gomez, J.P.Manaud, Y. Le Petitcorps and F.Girot, "Wear behaviour of cemented carbide tools in dry machining of aluminium alloy," in Wear Vol. 259(7-12), 2005, pp. 1177-1189.

22. Antônio Mariade, Souza Jr, Wisley Falco Sales, Sandro Cardoso Santos and Alisson Rocha Machado, "Enactment of single Si3N4 and mixed Si3N4+PCBN wiper cutting tools used to high speed face milling of cast iron" in International journal of machine tools and manufacture, Vol. 45(3), March 2005, pp. 335-344.

23. S.F.Scieszka, "Edge failure as a means of concurrently estimate the abrasion and edge fracture struggle of hardmetals," in Tribology International,Vol 38(9), September 2005, pp. 834-842.

24. M.Milfelner, F.CusJ.Balic, "An overview of data acquisition system for cutting force measuring and optimization in milling," in Journal of materials processing technology, Vol. 164-165, May 2005, pp. 1281-1288.

25. Z.G.Wang, M.Rahman and Y.S.Wong, "Tool wear features of binderless CBN tools used in high speed milling of titanium alloys," in Wear, Vol. 258(5-6), February 2005, pp. 752-758.

26. R.Zitoune, F.Collombet, F.Lachaud, R.Piquet and P.Pasquet, "Experiment-calculation comparison of the cutting conditions representative of the long fiber composite drilling phase," in Composites science and technology, Vol. 65(3-4), March 2005, pp. 455-466.

27. G. Prabhaharan, R. Ramesh and P. Asokan, "Concurrent optimization of assembly tolerances for quality with position control using scatter search approach ", in International Journal of production research, Vol. 45, 2007.

28. Ben A. Maguad, "The modern quality movement: Origins, development and trends," in Total quality management \& business Excellence, Vol. 17(2), 2006.
29. Bimal Nepal, Ratna Babu Chinnam, John Petrycia, Eric Brush, Colin Chisholm and Mark Hearn, "A Qualitybased business model for determining non-product investment: A Case study from a Ford Automotive Engine Plant," in Engineering management journal, Volume 19(3), 2007.

30. Gavriel Meirovich, "Quality of design and quality of conformance: Contingency and synergistic approaches," in Total quality management \& Business Excellence, Vol. 17(2), 2006.

31. Rita Arauz , Hirofumi Matsuo and Hideo Suzuki, "Measuring changes in quality management: An empirical analysis of Japanese manufacturing companies," in Total quality management \& Business excellence, Vol. 20(12), 2009.

32. Julia Brettschneider, François Collin, Benjamin M Bolstad and Terence P Speed, "Quality assessment for short oligonucleotide microarray data," in Technometrics, Vol. 50(3), 2008.

33. Amitava Mithra (2003) 'Fundamentals of quality control and improvement', Pearson education, 2nd edition. pp.35-50.

34. Cyric Donaldson, Goold.V.C (1976) ‘Tool Design', Tata McGraw-

Hill Education. pp 229-241.

35. Joseph R. Davis (1995) 'ASM: Speciality Handbook: Tool materials', ASM Internationals. pp 264-270.

36. P.S.G College of Technology (2012), Design data : Data book of Engineers. pp 11.1-11.13.

37. Tadeusz Stolarski, Nakasone. Y, Yoshimoto. S (2011)'Engineering analysis with ANSYS Software', Butterworth Heinemann Publisher.pp.330-345.

38. Philip F. Ostwald and Jairo Munaz(2005) 'Manufacturing process and systems', ninth edition.pp.165-169.

\section{AUTHORS PROFILE}

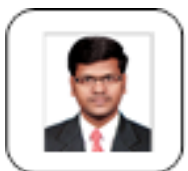

D. Sakthimurugan is an Assistant Professor in the Department of Mechanical Engineering at Easwari Engineering College, Chennai. He completed his Post Graduate in Industrial Engineering at Kumaraguru College of Technology, Coimbatore. He is specialized in Optimization techniques, Lean Six sigma, and also doing his research in the field of process optimization.

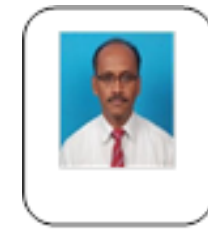

Manufacturing

systems Integration.
L. Antony Michael Raj is Professor in the Department of Mechanical Engineering at LoyolaICAM College of Engineering, Chennai. $\mathrm{He}$ received his doctorate degree from Anna University, Chennai. He completed his Master of Science in manufacturing systems Integration. $\mathrm{He}$ is specialized in Production systems Optimization and

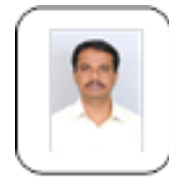

V. Antony Aroul Raj. V is Professor in the Department of Mechanical Engineering at Easwari Engineering College, Chennai. He received his doctorate degree from Anna University, Chennai. He completed his Post Graduate in Energy Engineering at Pondicherry Engineering College. He is specialized in Computational Fluid Dynamics application in the fields of drying, renewable energy, buildings and automobile.

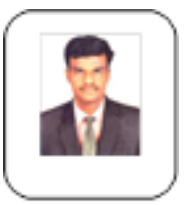

K. Thavasilingam is an Assistant Professor in the Department of Mechanical Engineering at Easwari Engineering College, Chennai. He completed his Post Graduate in Engineering Design at Anna University Regional center, Madurai. $\mathrm{He}$ is specialized in corrosion coating and material characterization. 
N. Bharath is an Assistant Professor in the Department of Mechanical Engineering at Easwari Engineering College, Chennai. He completed his Post Graduate in Manufacturing Engineering at Madras Institute of Technology, Chennai. He is specialized in Materials and unconventional machining processes. 